\title{
Rule Based Classification of Potential Snow Avalanche Areas
}

\author{
Nagarajan $\mathbf{R}^{1, *}$, Venkataraman $\mathbf{G}^{1}$, Snehamani ${ }^{2}$ \\ ${ }^{1}$ Center of Studies in Resources Engineering, Indian Institute of Technology, Bombay, Powai,Mumbai-400076, India \\ ${ }^{2}$ Snow and Avalanche Studies Establishment, DRDO, Him Parisar, Plot No 1, Sector 37A, Chandigarh - 160036 (UT), India \\ *Corresponding author: rn@iitb.ac.in
}

Copyright (C) 2014 Horizon Research Publishing All rights reserved.

\begin{abstract}
Snow avalanche events depend not only on the accumulated snow cover over the mountain slope but also the subsequent snowfall intensity. Spatial snow holding capacity of mountain slopes and the probability of initiation of snow avalanches over parts of Beas River valley, Himachal Pradesh, India, was attempted using maps showing terrain characteristics and satellite images along with meteorological information. Contributory factors in retaining the snowfall, snow fall variation and snow pack characteristics were ranked and assigned weightage towards the avalanche initiation based on the reported events in the region. Spatial distribution of Snow Accumulation Zone (SAZ), Snow fall Area(SFA) and Snow Pack Stability (SPS) assessment criteria was developed.
\end{abstract}

Keywords Snow Avalanche, Terrain, Meteorological Parameters, Ranking, Weighting, Rule Based Strategies

\section{Introduction}

The number of tourists visiting the snow covered Indian Himalayas for winter recreational facilities (holidays, skiing, snow surfing) are increasing from the previous years. In order to meet the requirements of the tourists, transportation network and buildings are being constructed in the mountainous areas. Global climate change could increase the frequency of extreme snowfall events and related disaster (snow avalanche) in mountainous regions. The rapid downward movement of snow (velocity $>5 \mathrm{~m} / \mathrm{sec}$ ) accumulated from the mountain slope is known as Snow Avalanche that affects the people, road network and winter sports facilities. The excess accumulation of snowfall, blasting or natural vibration (earthquake) in the vicinity triggers the event. The downward moving snow debris could be powdery or blocky and boulders and soil/trees are carried along with it. Starting zone of an avalanche is called as the formation zone from where the failed unstable snow pack begins to move. Run out zone when debris eventually comes to rest when the slope angle equals the static friction angle.
True forecast(McClung 2000) indicates the probability of an avalanche occurrence determined prior to the incremental changes in snowfall, based on the weather predictions. As, the information on the snow holding capacity of the slope is significant in the forecast of a region, there is a need to integrate the terrain, climatic parameters and internal factors of snow pack in avalanche warning.

\section{Review of Literature}

The Western Himalaya accounts for higher average snow cover at higher elevations due to winter Westerlies and northerly latitude, resulting in west-east gradient of snow cover (Bookhagen and Burbank, 2010). The snow cover peak in Western Himalaya is in February, January in Kashmir valley and end of March in Baspabasin (Kaur et al., 2009). The snow depletion is in January for area between 2000 and $4000 \mathrm{~m}$, March for 4000 and $6000 \mathrm{~m}$, and April in the region above $6000 \mathrm{~m}$ for Tibetan Plateau (Pu et al., 2007).Slab and wet loose snow avalanches and sluffing events in Indian Himalayas are due to the increased moisture content which causes speedy flow of free water in snow cover (Sharma et al 2000). Vegetation coverage cannot stop them, but it generally restricts the amount of snow that can be involved in the start of an avalanche (Ciolliet al. 1998). The tree line extends up to approximately $3500 \mathrm{~m}$. This observatory is below tree line and receives good amount of snow. Snow pack is relatively deep and warm, a feature of maritime snow climate (Singh and Ganju (2006). One among the preventive measures of snow avalanche is ski areas is to release the accumulated snow by explosives (Höller 2007). The climate and land-use have considerable impacts on avalanches (Laternser and Schneebeli 2002).

Snow avalanche forecast indicates the avalanche releases, based on analyses measured snow and weather parameters which highlights the avalanche formation process. It is estimated by weighting the influence of contributory factors (terrain, new snow, wind temperature and snowpack stratigraphy) in a specific situation and estimating the avalanche probability and characteristics (Schweizer et al 
2008). Seluck (2013) used the Geographical information system (GIS) based multi-criteria decision analysis (MCDA) in the identification of avalanche hazard areas in Bitlis Province of Turkey. GIS layers of elevation, slope, aspect, vegetation density and land use were used. Knowledge Based strategies perform (Ian McCammon and Pascal Hageli 2007) well when employed by experienced decision makers under resources rich conditions and suffer from few disadvantages such as conflicting or ambiguous information. However, Rule based (RB) strategies (Rasmussen 1982) take the form of If-Then relationships that are triggered by observed cues leading to relative avalanche risk. Indirect indicators of snow pack stress and strength conditions coupled with terrain information could be effectively used in hazard mapping. The event forecasting involves static terrain information, dynamic snow characteristics and accumulation on the temporal and spatial scale (McClung \&Scheweizer 1993).

\section{Objective}

The objective of this case study is to demarcate snow avalanche potential areas in parts over Beas river basin, using rule based system with the help of terrain, meteorological and snow mass/pack conditions.

\section{Study Area}

Snow avalanches occur during winter months in the snowbound belt of Western and Central Himalaya. Several avalanches are reported from the Beas valley, located on the windward side of PirPanchal range of Indian Himalayas. The Palchan - Rohtang section of highway connecting Kulu Manali - Ladakh passes through it (Figure 1). Climate of the study area (350 sq km area of Beas basin spread over $32^{\circ} 20^{\circ}$ $\mathrm{N}-32^{0} 25^{\prime} \mathrm{N}$ and $\left.77^{\circ} 05^{\prime} \mathrm{E}-77^{\circ} 15^{\prime} \mathrm{E}\right)$ is cool and dry, with cold season from October to February, hot season from March to June and rainy season from July to September. It receives heavy dry to moist snowfall during November to February, moderate high temperature (at times goes between $0^{0} \mathrm{C}$ and $-15^{\circ} \mathrm{C}$ ). Snowfall, generally, occurs in December to March at elevation above $2000 \mathrm{~m}$. The maximum rainfall occurs during July to September and minimum rainfall occurs during October to January. Temperatures range from a mean daily minimum of between -15 and $0^{\circ} \mathrm{C}$ in January to mean maximum of 20 to $30^{\circ} \mathrm{C}$ in June.The reported snow avalanches of this region are from: - 1) slope of $30^{\circ}$ to $50^{\circ}, 2$ ) by a terrain altitude of $2500-4500 \mathrm{~m}$ mean sea level (MSL); 3) slope aspects on south and north is $45^{\circ}$; 5) during Dry snow periods of November to middle of February; moist snowmid February to mid march; wet snowmid March onwards; average precipitation and having a 6) total snow of $1083 \mathrm{~cm}$, total water equivalent $(\mathrm{mm}) 1058.25 ; 7)$ average maximum standing snow $111 / 256 \mathrm{~cm}$ and 8) average minimum temperature is $-2.4^{\circ} \mathrm{C}$, lowest $-12^{0} \mathrm{C}$; average maximum $6.3^{\circ} \mathrm{C}$; highest $17^{\circ} \mathrm{C}$. Snow avalanche warnings are issued based on the fresh snow fall for $24 \mathrm{hrs}$ and standing snow.

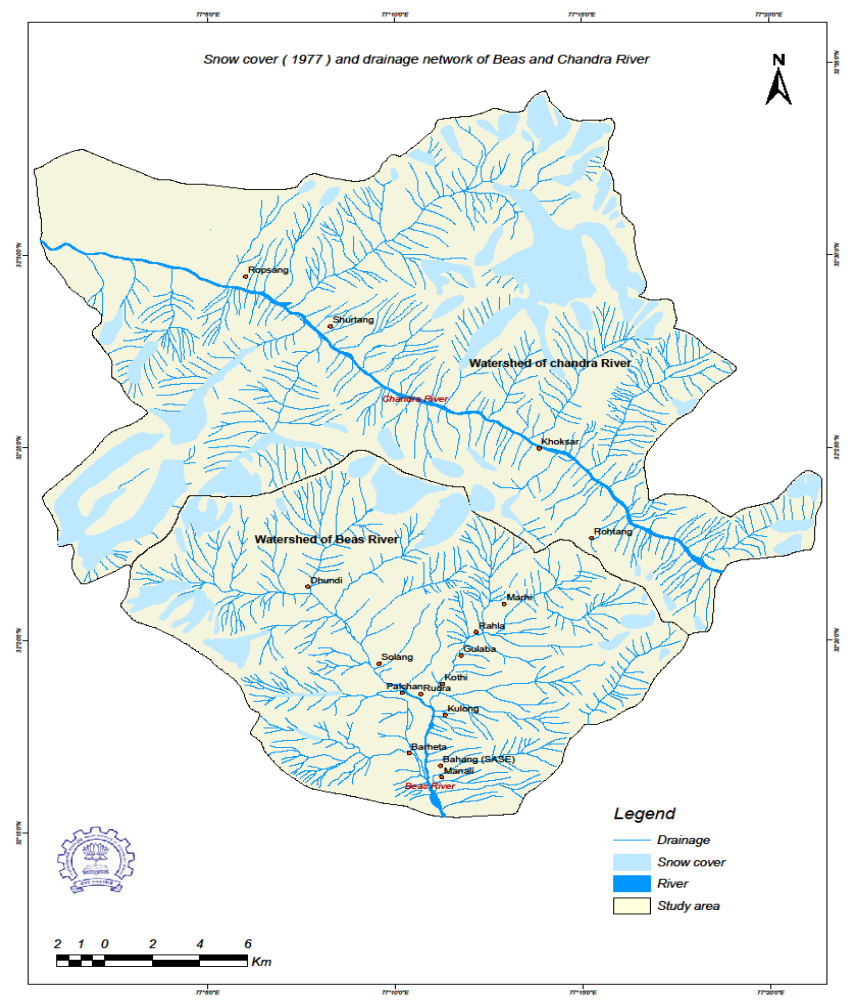

Figure 1. Location Beas catchment (study area) and Chandra River basin 
Table 1. Terrain characteristics of reported avalanches (Courtesy: SASE Chandigarh)

\begin{tabular}{|c|c|c|c|c|c|c|c|}
\hline Profile & Location & Formation zone & Run out & Slope & Slope aspect & Event dates & Area (sq.m) \\
\hline P 2 & $\begin{array}{c}32^{0} 19^{\prime} 15.51^{\prime \prime} \mathrm{N} \\
77^{0} 09^{\prime} 00.66^{\prime \prime} \mathrm{E}\end{array}$ & $2750-2840 \mathrm{~m}$ & $2520 \mathrm{~m}$ & $32^{0}$ & $\mathrm{E}$ & & 174296.12 \\
\hline P 3 & $\begin{array}{c}32^{0} 19^{\prime} 23.08^{\prime \prime} \mathrm{N} \\
77^{0} 08^{\prime} 56.98^{\prime \prime} \mathrm{E}\end{array}$ & $3100-4200 \mathrm{~m}$ & $2500 \mathrm{~m}$ & $37^{0}$ & $\mathrm{~N}$ & 9.2 .2004 & 2911590.35 \\
\hline P 4 & $\begin{array}{c}32^{0} 19^{\prime} 54.86^{\prime \prime} \mathrm{N} \\
77^{0} 08^{\prime} 47.00^{\prime \prime} \mathrm{E}\end{array}$ & $3000-3250 \mathrm{~m}$ & $2600 \mathrm{~m}$ & $45^{0}$ & $\mathrm{~N}$ & & 349898.69 \\
\hline P 5 & $\begin{array}{c}32^{0} 20^{\prime} 10.04^{\prime \prime} \mathrm{N} \\
77^{0} 08^{\prime} 31.63^{\prime \prime} \mathrm{E}\end{array}$ & $3030-3210 \mathrm{~m}$ & $2645 \mathrm{~m}$ & $37^{0}$ & $\mathrm{~N}$ & 9.2 .2004 & 256529.24 \\
\hline P 6 & $\begin{array}{c}32^{0} 20^{\prime} 20.23^{\prime \prime} \mathrm{N} \\
77^{0} 08^{\prime} 26.38^{\prime \prime} \mathrm{E}\end{array}$ & $3130-3305 \mathrm{~m}$ & $2650 \mathrm{~m}$ & $43^{0}$ & $\mathrm{~N}$ & 1.2 .2004 & 229864.74 \\
\hline P 7 & $\begin{array}{c}32^{0} 20^{\prime} 35.02^{\prime \prime} \mathrm{N} \\
77^{0} 08^{\prime} 10.99^{\prime \prime} \mathrm{E}\end{array}$ & $3000-3850 \mathrm{~m}$ & $2700 \mathrm{~m}$ & $40^{0}$ & $\mathrm{~N}$ & 1.2 .2004 & 3381094.85 \\
\hline P 8 & $\begin{array}{c}32^{0} 20^{\prime} 54.45^{\prime \prime} \mathrm{N} 77^{0} \\
07^{\prime} 52.99^{\prime \prime} \mathrm{E}\end{array}$ & $3055-3460 \mathrm{~m}$ & $2840 \mathrm{~m}$ & $36^{0}$ & $\mathrm{~N}$ & & 157090.21 \\
\hline P 9 & $\begin{array}{c}32^{0} 21^{\prime} 01.22^{\prime \prime} \mathrm{N} \\
77^{0} 07^{\prime} 47.56^{\prime \prime} \mathrm{E}\end{array}$ & $3030-3175 \mathrm{~m}$ & $2845 \mathrm{~m}$ & $38^{0}$ & $\mathrm{E}$ & & 104977.99 \\
\hline P 10 & $\begin{array}{c}32^{0} 20^{\prime} 08.99^{\prime \prime} \mathrm{N} \\
77^{0} 07^{\prime} 36.16^{\prime \prime} \mathrm{E}\end{array}$ & $3000-3525 \mathrm{~m}$ & $2840 \mathrm{~m}$ & $37^{0}$ & $\mathrm{~N}$ to NE & $\begin{array}{c}2.3 .2005,3.2 .2 .005, \\
17.3 .2005,19.3 .2005, \\
18.1 .2006\end{array}$ & 207796.25 \\
\hline
\end{tabular}

Table 2. Snow characteristics and potential avalanche type

\begin{tabular}{|c|c|c|c|c|}
\hline Snow type & $\begin{array}{l}\text { Grain size } \\
(\mathrm{mm})\end{array}$ & Density (g/cc) & $\begin{array}{c}\text { Snow } \\
\text { temperature }\end{array}$ & Avalanche type \\
\hline $\begin{array}{l}\text { Dry snow } \\
\text { (fresh) }\end{array}$ & Fine 0.2 to 0.5 & $0.05-0.2$ & $<0^{0} \mathrm{C}$ & Airborne avalanche \\
\hline Dry snow (old) & $\begin{array}{c}\text { Coarse } 0.5 \text { to } \\
2.0\end{array}$ & $0.2-0$ & & $\begin{array}{c}\text { Dry loose avalanche } \\
\text { Soft slab avalanche } \\
\text { Hard slab avalanche and delayed action on dry and old snow after melt } \\
\text { freeze }\end{array}$ \\
\hline Moist snow & $\begin{array}{c}\text { Greater than } \\
2.0\end{array}$ & 0.3 to 0.4 & 0 & Soft slab avalanche delayed action after melt freeze \\
\hline Wet snow & $\begin{array}{c}\text { Greater than } \\
2.0\end{array}$ & $\begin{array}{c}\text { Greater than } \\
0.4\end{array}$ & & $\begin{array}{c}\text { Hard slab avalanche delayed action after melt freeze } \\
\text { Wet slab avalanche direct and delayed action } \\
\text { Melt or thaw avalanche/wet loose snow avalanche delayed action. } \\
\text { Slush avalanche direction and delayed action } \\
\end{array}$ \\
\hline
\end{tabular}

There are mainly two types of avalanche events: (a) avalanches releasing during heavy snowfall and (b) wet snow avalanches during February/March/April. The terrain and snow characteristics of the reported avalanches of this region are shown in Table 1 and Table 2 respectively.

\section{Methodology}

The amount of snowfall that can be stuck to the surface of the hill slope depends on the terrain parameters such as elevation, slope angle, slope aspect, surface curvature, roughness and land cover. Contour lines (20 meter intervals) from the Survey of India topographical sheets were digitized and estimated the slope parameters and slope profiles drainage lines that act as transport route for down ward movement of avalanche debris. Figure 2 shows the profile of the drainage that act as run out zone from formation zone at the top of the hill $(3850 \mathrm{~m})$. Initial loose snow fall fills up the micro level depressions. Subsequent average profiles ranges between 20 and $28^{\circ}$. The anticipated run out distance of slab avalanche is $90.5 \mathrm{~m}$ beyond (point $\mathrm{A}$ is on the river) that terminates at the river onto the other side of the valley. Spatial snow cover and the vegetation growth are important in the initiation and runout. Indian Remote Sensing (IRS) Satellite data of, LISS (Linear Image Scanning System) of 2 December 2004 that depicts the surface cover was used. Figure 3 is the Indian Remote sensing satellite image showing the snow and non-snow covered areas. The snow fall, temperature and number of number of snowfall days were collected from the weather stations located in the region. Table 3 shows the snow fall intensity, inter-snowfall gaps, air temperatures and accumulated snow thickness estimation. Snow metamorphism and compactness occurs during the inter-snow fall event. Snow pit information about the grain size of the compacted and non-compacted snow on the mountain slope was demarcated. 


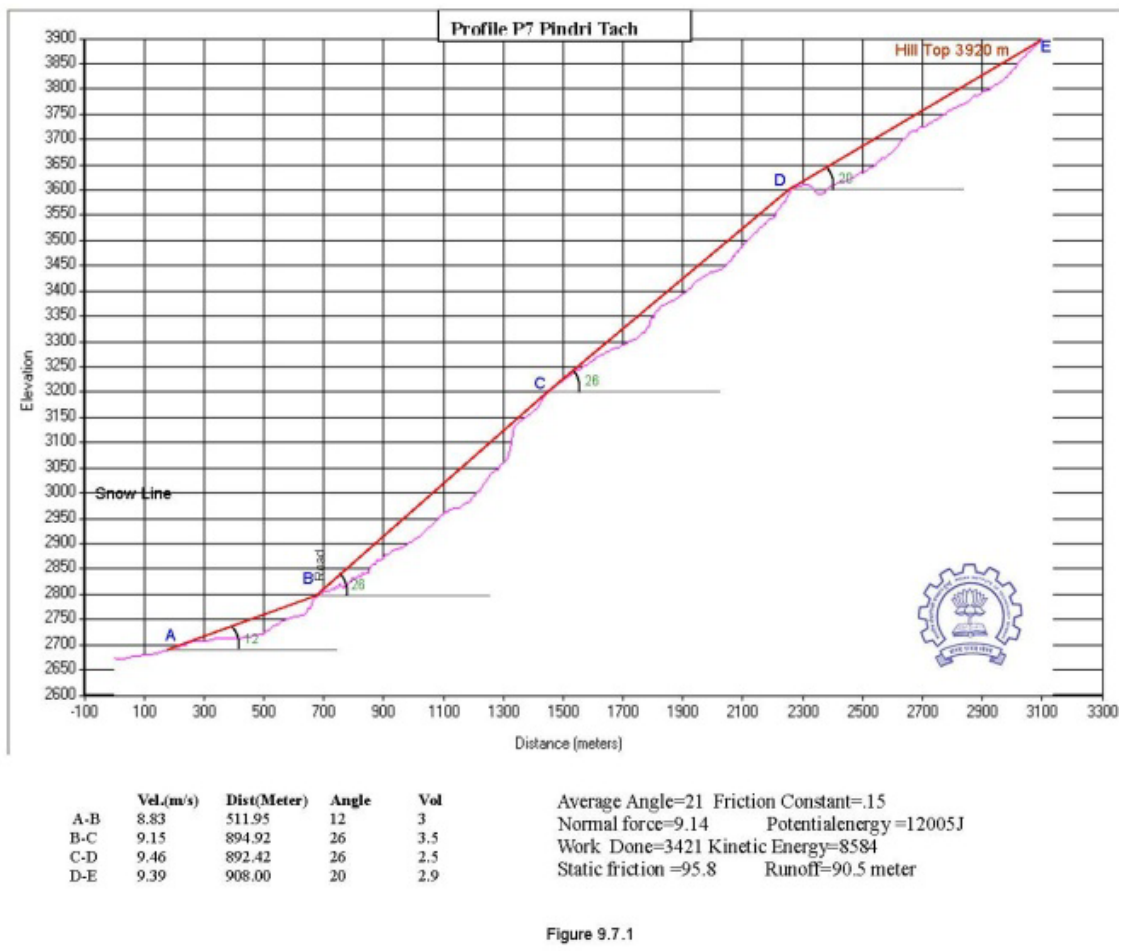

Figure 2. Slope profile showing actual and anticipated slope after compaction of initial snow fall

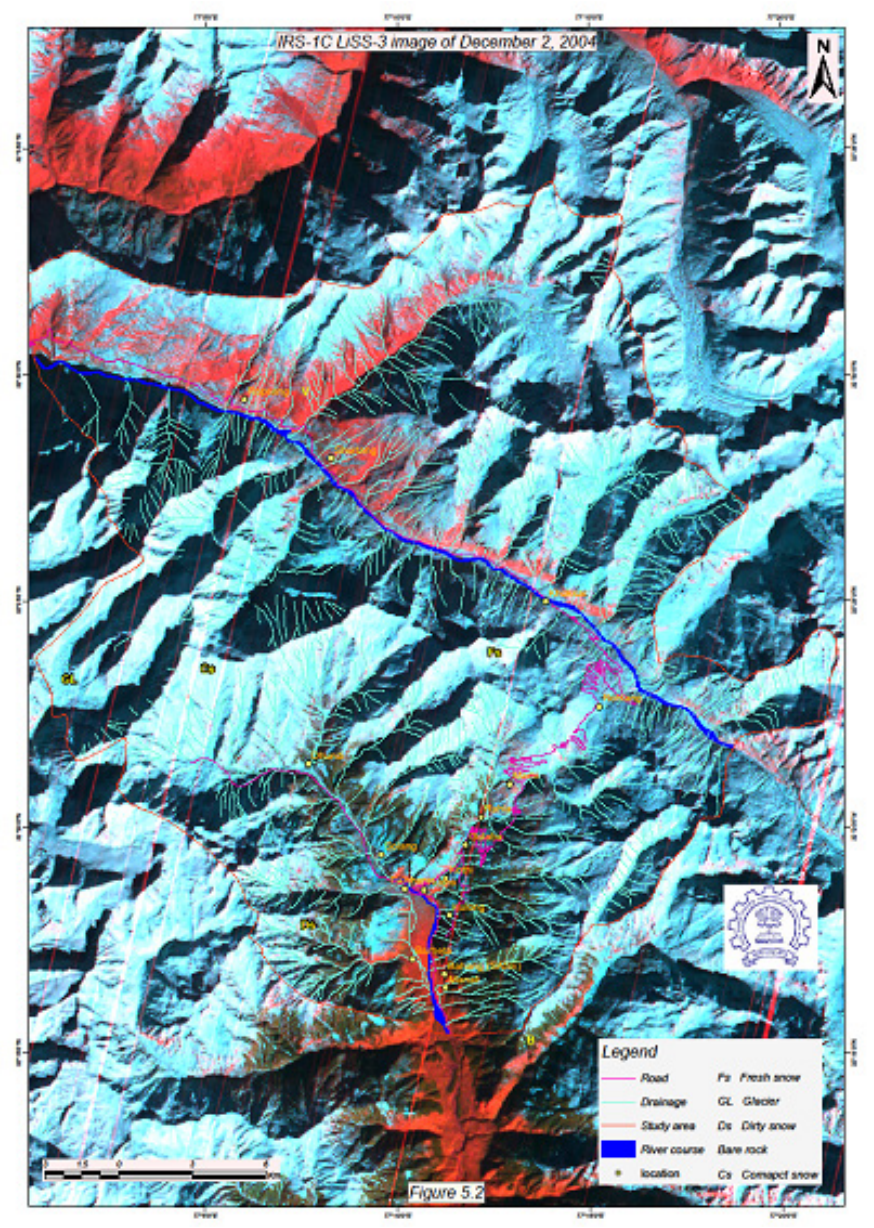

Figure 3. Satellite image (2 December 2004) showing the snow cover and vegetation cover of Beas valley 
Table 3. Snow fall and temperature recorded at Dhundi Station $\left(32^{\circ} 21^{\prime} 20^{\prime \prime} \mathrm{N}\right.$ and $\left.77^{\circ} 07^{\prime} 41^{\prime \prime} \mathrm{E}\right)$

\begin{tabular}{|c|c|c|c|c|c|}
\hline \multirow{2}{*}{ Snow fall Event } & \multirow{2}{*}{ Date } & \multicolumn{2}{|c|}{ Snow fall $(\mathrm{cm})}$. & \multicolumn{2}{|c|}{ Air Temperature $\left({ }^{0} \mathrm{C}\right)$} \\
\hline & & Freshsnow & Standing snow & Maximum $\left({ }^{0} \mathrm{C}\right)$ & Minimum $\left({ }^{0} \mathrm{C}\right)$ \\
\hline \multirow{2}{*}{1} & 18 Nov 2000 & \multirow{2}{*}{25} & \multirow{2}{*}{8} & \multirow{2}{*}{47} & \multirow{2}{*}{$\begin{array}{l}-1 \\
-3\end{array}$} \\
\hline & 19 Nov 2000 & & & & \\
\hline \multicolumn{6}{|c|}{2 Days of no snow fall } \\
\hline \multirow{3}{*}{2} & 22 Nov'00 & \multirow{3}{*}{24} & \multirow{3}{*}{13} & \multirow{3}{*}{$\begin{array}{l}3- \\
4\end{array}$} & \multirow{3}{*}{$\begin{array}{l}-1- \\
-1\end{array}$} \\
\hline & 23 Nov’00 & & & & \\
\hline & 24 Nov'00 & & & & \\
\hline \multicolumn{6}{|c|}{2 Days of no snow fall } \\
\hline \multirow{2}{*}{3} & 27 Nov'00 & \multirow{2}{*}{12} & 12 & $0-$ & -3 \\
\hline & 28 Nov'00 & & 12 & 2 & -6 \\
\hline & & $9 \mathrm{Da}$ & snow fall & & \\
\hline 4 & 8 Dec'00 & 10 & 7 & 5 & -2 \\
\hline & & $8 \mathrm{Da}$ & snow fall & & \\
\hline 5 & 17 Dec'00 & 7 & 2 & 7- & $0-$ \\
\hline 5 & 18 Dec'00 & 1 & 2 & 5 & 1 \\
\hline & & $12 \mathrm{D}$ & o snow fall & & \\
\hline 6 & 31 Dec'00 & 9 & 6 & $1-$ & -1 \\
\hline & 1 Jan'01 & & & 1 & -3 \\
\hline & & $10 \mathrm{D}$ & o snow fall & & \\
\hline 7 & 12 Jan'01 & 2 & 2 & 3 & 0 \\
\hline & & $9 \mathrm{Da}$ & snow fall & & \\
\hline 8 & 22 Jan'01 & 79 & 50 & $-4-$ & -5 \\
\hline 0 & 23 Jan'01 & 19 & 0 & 1 & -8 \\
\hline & & $21 \mathrm{D}$ & o snow fall & & \\
\hline 0 & 14 Feb’01 & 53 & 26 & $1-$ & -1 \\
\hline 3 & 15 Feb’01 & נת & 20 & 7 & -2 \\
\hline & & $1 \mathrm{D}$ & snow fall & & \\
\hline & 17 Feb’01 & 17 & 24 & 2 & -1 \\
\hline & & $2 \mathrm{Da}$ & snow fall & & \\
\hline 10 & 20 Feb’01 & 17 & 21 & 7- & 1 \\
\hline 10 & $21 \mathrm{Feb} 01$ & 11 & 21 & 8 & -5 \\
\hline & & $1 \mathrm{D}$ & snow fall & & \\
\hline & 23 Feb’01 & & & & \\
\hline 11 & 24 Feb’01 & 61 & 51 & $3-$ & -1 \\
\hline 11 & 25 Feb’01 & 01 & & 3 & -5 \\
\hline & 26 Feb'01 & & & & \\
\hline & & $14 \mathrm{D}$ & o snow fall & & \\
\hline & 13 Mar'01 & & & & \\
\hline 12 & 14 Mar'01 & 21 & 5 & 7 & $\begin{array}{l}2 \\
--5\end{array}$ \\
\hline & 15 Mar'01 & & & & \\
\hline & & $4 \mathrm{Da}$ & snow fall & & \\
\hline & 20 Mar'01 & & & & \\
\hline 13 & 21 Mar'01 & 105 & 46 & $1-$ & 0 \\
\hline 10 & 22 Mar'01 & & & 6 & -3 \\
\hline & 23 Mar'01 & & & & \\
\hline & & $4 \mathrm{Da}$ & snow fall & & \\
\hline & 28 Mar '01 & & & & \\
\hline 14 & 29 Mar '01 & 67 & 46 & $7-$ & $4-1$ \\
\hline & 30 Mar'01 & & & & \\
\hline & & $4 \mathrm{D}$ & snow fall & & \\
\hline 15 & 4 April’01 & 4 & 15 & 8 & 0 \\
\hline & & $13 \mathrm{dc}$ & o snow fall & & \\
\hline 16 & 18 April'01 & 5 & 3 & 6 & 1 \\
\hline & & $1 \mathrm{Da}$ & snow fall & & \\
\hline 17 & 20 April'01 & 18 & 18 & 6 & -0.5 \\
\hline
\end{tabular}




\section{Parameters of Influence}

Terrain parameters that influence the avalanches are-

Elevation (E)influences avalanche initiation because snowfall, wind, and temperature vary with elevation. The wind speed at high altitudes increases with height due to the characteristics of global wind belts. The amount of wind-transported snow generally increases with height on mountains. Moreover, snow that falls on lower elevations often melts in the warmer air below. Wind and sun, and ground cover condition makes the snow pack on higher elevations more vulnerable to avalanches than lower elevations. $3000 \mathrm{~m}$ above MSL is the snow line of this Northern Himalaya. The altitude was grouped into four classes and the probability of event increases from areas above $3000 \mathrm{~m}$. Five classes were deciphered and assigned weightage of 10 .

Hill slope (SL) - Most of the avalanche accidents happens in an area where the slope angle is greater than $30^{\circ}$. On rare occasions, avalanches start on gentle slopes of less than $25^{\circ}$ (slash flow involving wet snow with high water content), but generally the shear stress induced by gravity is not large enough to initiate an avalanche (Ancey 2009). Because the amounts of snow deposition on steep slopes are limited, avalanches are very frequent and of small dimension for inclinations in excess of $45^{\circ}$ to $50^{\circ}$. The slope values were divided into 4 classes. ) Below $10^{\circ}$ : practically no avalanches are triggered; b) $10^{\circ}-28^{\circ}$ : Avalanches are scarce; c) $28^{\circ}-45^{\circ}$ : Major danger zone for avalanche triggering; d) above $45^{\circ}$ : High avalanche frequency, but low snow accumulation due to steepness. The starting zone of reported avalanche ranges between $27^{\circ}$ to $50^{\circ}$ and slush flow that takes place in wet snow with water content from slope angle areas of $50^{\circ}$. Five classes were deciphered and assigned weightage of 35 .

Orientation of slope $(\mathrm{Sd})$ with respect to sun has a strong influence on day-to-day stability of snowpack. In winter, shadowy slopes receive minimum incoming radiation from the sun and conversely lose heat by long-wave radiation and the snowpack develop weak layers (faceted crystals, depth hoar). Wet snow avalanches take place from the southern facets during spring time, owing to snow fusion and decrease the friction caused by the rise in pressure within the snow mantle. On the hand, windward slopes experience a shallower and compacted snow cover. Five classes were deciphered and assigned weightage of 25 .

Surface Curvature $(\mathrm{Sc})$ - Convex surface causes an unstable condition in the snow mantle that allows the fracture development due to stress while concave surfaces favor the snow accumulation and its stabilization. Three classes were deciphered and assigned weightage of 20.

Ground cover / surface roughness (Sve) is important in the anchorage of snow cover to the ground surfaces that favor release of snow debris. Ground covered with large boulders and zones cut by several ridges limit the quantum of snow that can be involved in the initiation of an avalanche. Large and open slopes with smooth ground surface favor the avalanche release. The stress distribution within the snow pack and variation in its depth depend on the longitudinal shape of the ground. Convex slops concentrate tensile stresses and are associated with significant variation in the snow cover depth favoring snow pack instability. It is reported that $90 \%$ of avalanches occur terrain with a green cover with average height is less than $2 \mathrm{~m}$. The chance of avalanche triggered from forest area is almost nil. Five classes were deciphered and assigned weightage of 10 .

\section{Meteorology}

The spatial variability of daily precipitation is not only driven by large-scale weather situations, but also highly dependent on topography especially on elevation. However, in contrast to air temperature this relationship is not linear. The sunshine duration (S) depends on the season, cloudiness and topography and the conditions observed at nearest weather station are used.

Amount of fresh snowfall (Fs) increases the depth of accumulation and $30 \mathrm{~cm} /$ day is of critical. $1 \mathrm{~m}$ of antecedent snow in the past 3 days has reported to have triggered large scale avalanches in the European Mountains. The snow fall intensity of $2 \mathrm{~cm} / \mathrm{hr}$ or more increases the triggering potential. Manali recorded $80 \mathrm{~cm}$ of snow while Dhundhi, Mari and Rohtang Pass had $120 \mathrm{~cm}, 150 \mathrm{~cm}$ and $200 \mathrm{~cm}$ of fresh snowfall, reports reaching here said on January 17, 2012 affected vehicular traffic in the area. Five classes were deciphered and assigned weightage of 50 .

Air temperature (Ta) Increased Temperature Gradient (TG) of layers enhances the strength by sintering and instability may reappear during spring by melting of the sintering bonds. It is due to conditions that can be significantly warmer on the bottom of the snow than the snow surface. Snow crystals resulting in from destructive equi-temperature (ET) metamorphism make good snowballs that compact easily and the part of the snow pack can become very hard and dense. Wind factor significantly influences the stability of snow pack that causes uneven snow redistribution (accumulation on the leeward slopes) accelerates snow metamorphism form cornices whose collapses may trigger avalanche. In late winter air temperature rises, sometimes introduces the weak layers within the snowpack due to melt-freeze which may trigger the avalanches. The melt water reduces the strength of snow layers significantly and poses the wet snow avalanche hazard. Three classes were deciphered and assigned weightage of 10 .

Wind direction $(\mathrm{Wd})$ and wind direction are dependent on topography. Loading of snow adds weight on the slope and the fastest way of loading is carried out by wind. Wind erodes from the upwind side of an obstacle such as ridges and it deposits on the downward wind side and wind can deposit snow ten times more rapidly than snow fall. Four classes were deciphered and assigned weightage of 10 .

Wind Speed (Ws) dry snow fallen on the ground is redistributed by wind drift. Snow from high crest area is blown away to cause excessive deposition in depression zones $f$ avalanche formation and on leveled ground where 
snow drift glaciers may form. Wind speed of $10 \mathrm{~km} / \mathrm{hr}$ can transport crystals of diameter of $1-2 \mathrm{~mm}$ to a distance of 100 to $500 \mathrm{~m}$ on an average. It also toughens the surface of snow and crust formation. Wind speed is the highest at isolated summits and ridges. Average wind speed of $24 \mathrm{hrs}$ reveals that most of the avalanche activities took place during calm or nearly calm days. It is observed that during or immediately after snowfall, there is either no wind or moderate wind. The maximum avalanches took places during cloudy days (6 kta).Three classes were deciphered and assigned weightage of 30 .

\section{Snow}

Snow Temperature (Ts)- Large temperature gradients during cold clear weather that cause the snow surface to become very cold and gain strength by sintering and instability take place by melting of the sintering bonds. The upper snow pack surface is subjected to cold air and bottom portion by the summer temperature stored in the rock, enhancing the melt. Mass becomes stiffer and stronger when it is colder. It also takes on increased brittleness in character with respect to fracture characteristics as the snow temperature decreases. Three classes were deciphered and assigned weightage of 10 .

Grain size of snow (Gs) of newly fallen crystals (large dimension of average crystal) is identified in the field using International Commission on Snow and Ice's (ICSI 1990) nomenclature. Significant difference in grain size amidst layers enhances the instability condition. Fine grained snow with rounded shape has the highest strength. Weak layers of skier triggered avalanches typically consist of surface hoar faceted (grains large and plane faces) or depth hoar. Rain plays a complex role in snow metamorphism. In dry snow, a small increase in the liquid water content $(\mathrm{LWC}<0.5$ percent) does not significantly affect the mechanical properties of snow. Heavy rain reduces a rapid and noticeable increase in LWC which results in a drop in the shear strength.Five classes were deciphered and assigned weightage of 10.Ten classes of Grain shape (Gsh) were deciphered and assigned weightage of 10. Grain shape (Gsh). Four classes of Snow type (Sty)were deciphered and assigned weightage of 20.Three classes of Snow type (Sty)were deciphered and assigned weightage of 20.
Snow mass structure (layers) (Spl) is the resultant from successive snowfalls. Stability of the mass depends on the bonds between layers and their cohesion. Heterogeneous snow pack made up of weak and stiff layers are more unstable than homogenous snow packs. Weak layers having larger grain size (greater than $1 \mathrm{~mm}$ ), low hardness and persistent grain form and interfaces payer have grain size greater than $0.5 \mathrm{~mm}$ and larger variation in hardness indicate instability, as does a depth to the interface between $20 \mathrm{~cm}$ and $85 \mathrm{~cm}$. Persistent weak layers that have been buried for some days or weeks become rounded and less critical but frequent rounded and are less critical but frequently show clear shears. The seasonal snowpack grows in layered structure with each layer having different physical and mechanical characteristics. The snowpack gets stratified because of successive snow events throughout the winter season and each snow event encounters a different set of meteorological parameters at the time of its occurrence and afterward.Five classes were deciphered and assigned weightage of 30 .

Slope deformation occurs on slope covered by snow is due to -1) in tension the grains are pulled part, 2) during compression, the grains are forced together and 3) in shear the grains are forced past each other. The snow pack characterization of individual zones could be deduced from a representative profile, the current weather situation and local knowledge about the predominant processes. A typical avalanche site can be divided into three zones, viz. (a) formation zone, with a slope angle of $30-50^{\circ}$, (b) middle zone, with a slope angle of $15-30^{\circ}$ and (c) run out zone, with a slope angle of less than $15^{\circ}$. Generally, an avalanche starts at formation zone, attains a maximum speed at middle zone and comes to halt at run out zone by depositing the snow mass,

The contributing parameters were grouped into classes and the classes intervals were made in such a way it represent the ground condition. The contributions of individual parameters were assigned as weightages. Depending the on the physical condition of an area, a cumulative of snow avalanche index will be calculated. Significant terrain, Meteorological and Snow pack parameters are given in Table 4 Table 5 and Table 6 respectively. 
Table 4. Significant Terrain parameters and their ranks and assigned weights

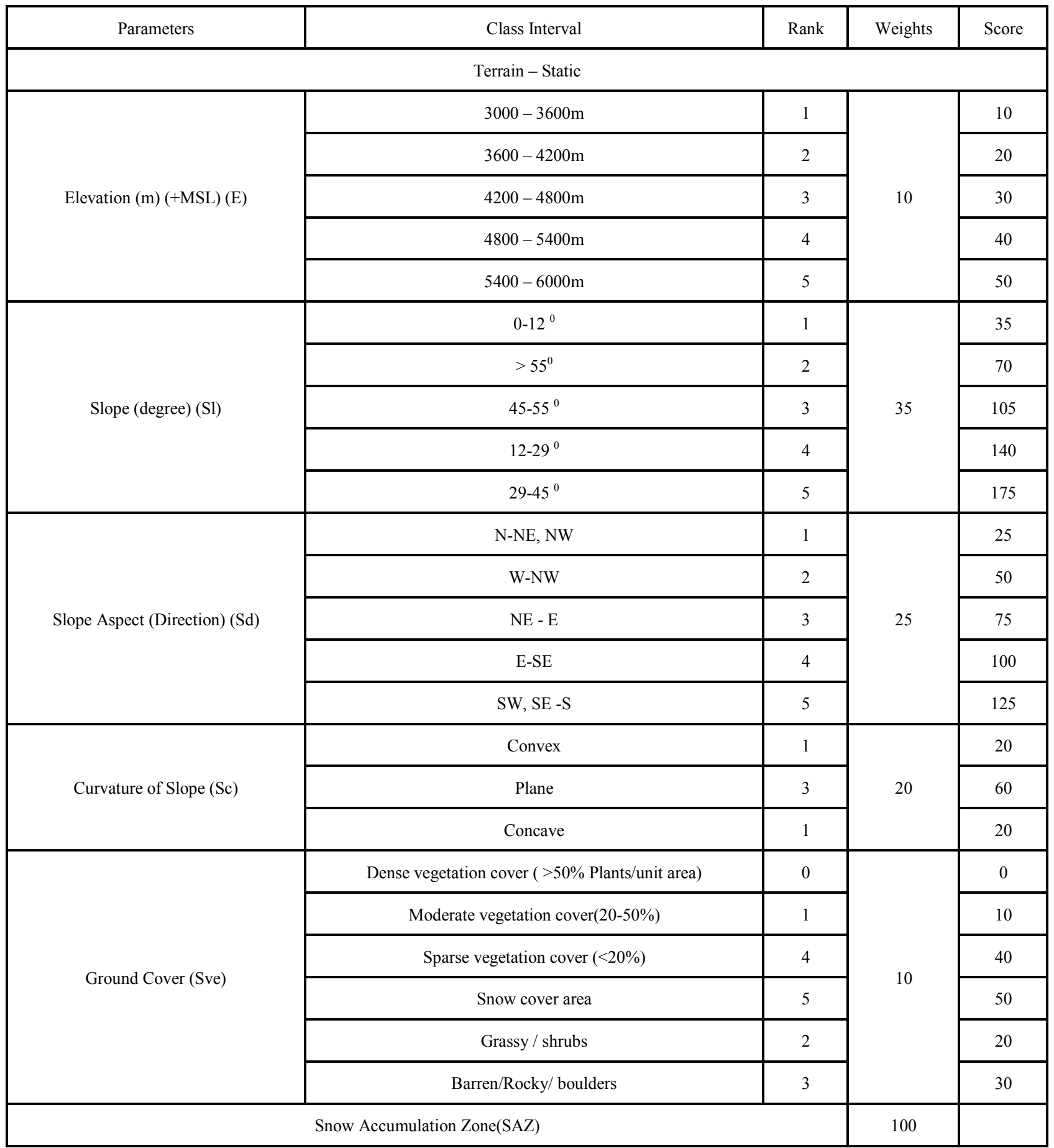


Table 5. Meteorological parameters and their assigned weights

\begin{tabular}{|c|c|c|c|c|}
\hline Parameters & Class Interval & Rank & Weights & Score \\
\hline \multirow{5}{*}{ Daily Fresh-Snow Fall(cm.) - (Fs) } & $0-10$ & 1 & \multirow{5}{*}{50} & 50 \\
\hline & $10-20$ & 2 & & 100 \\
\hline & $20-50$ & 3 & & 150 \\
\hline & $50-80$ & 4 & & 200 \\
\hline & $>80$ & 5 & & 250 \\
\hline \multirow{3}{*}{ Air Temperature (0C)(Ta) } & -4 to +4 & 0 & \multirow{3}{*}{10} & 0 \\
\hline & -4 to -15 & 1 & & 10 \\
\hline & +4 to +18 & 2 & & 20 \\
\hline \multirow{4}{*}{ Wind Direction (Wd) } & $0-450$ & 0 & \multirow{4}{*}{10} & 0 \\
\hline & $450-900$ & 1 & & 10 \\
\hline & $900-1350$ & 2 & & 20 \\
\hline & $1350-1800$ & 3 & & 30 \\
\hline \multirow{3}{*}{ Wind Speed (km/hr.)(Ws) } & $<10$ & 0 & \multirow{3}{*}{30} & 0 \\
\hline & $10-35$ & 1 & & 30 \\
\hline & $>35$ & 2 & & 60 \\
\hline \multicolumn{3}{|c|}{ Snow fall area (SFA) } & 100 & \\
\hline
\end{tabular}


Table 6. Significant Snow pack parameters and their assigned weight

\begin{tabular}{|c|c|c|c|c|}
\hline Parameters & Class Interval & Rank & Weights & Score \\
\hline \multirow{3}{*}{ Surface Snow Temperature $\left({ }^{0} \mathrm{C}\right)(\mathrm{Ts})$} & $>0^{0} \mathrm{C}$ & 1 & \multirow{3}{*}{10} & 10 \\
\hline & $0^{0} \mathrm{C}$ to $-10^{0} \mathrm{C}$ & 1 & & 10 \\
\hline & $<-10^{\circ} \mathrm{C}$ & 2 & & 20 \\
\hline \multirow{6}{*}{ Snow Grain Size $(\mathrm{mm})(\mathrm{Gs})$} & Less than $1 \mathrm{~mm}$ (Very Fine) & 5 & \multirow{6}{*}{10} & 50 \\
\hline & 1 - 2 (Fine) & 1 & & 10 \\
\hline & $2-3$ (Medium) & 2 & & 20 \\
\hline & $3-4$ (Coarse) & 3 & & 30 \\
\hline & 4 - 5 (Very Coarse) & 4 & & 40 \\
\hline & $>5$ (Extreme) & 5 & & 50 \\
\hline \multirow{10}{*}{ Grain-Shape(Gsh) } & Fresh Snow & 1 & \multirow{10}{*}{10} & 10 \\
\hline & Felt Like & 1 & & 10 \\
\hline & Rounded Grain & 2 & & 20 \\
\hline & Depth Hoar & 5 & & 50 \\
\hline & Melt Grain & 1 & & 10 \\
\hline & Surface Hoar & 4 & & 40 \\
\hline & Ice & 1 & & 10 \\
\hline & Sugar Grain & 3 & & 30 \\
\hline & Faceted Crystals & 4 & & 40 \\
\hline & Crust & 2 & & 20 \\
\hline \multirow{4}{*}{ Snow type (Sty) } & Dry snow & 4 & \multirow{4}{*}{20} & 80 \\
\hline & Moist Snow & 3 & & 60 \\
\hline & Wet Snow & 5 & & 100 \\
\hline & Slush & 1 & & 10 \\
\hline \multirow{2}{*}{ Standing snow (Sts) } & $<50 \mathrm{~cm}$ & 1 & \multirow{2}{*}{20} & 20 \\
\hline & $50-300 \mathrm{~cm}$ & 2 & & 40 \\
\hline
\end{tabular}




\begin{tabular}{|c|c|c|c|c|}
\hline & $>300 \mathrm{~cm}$ & 3 & & 60 \\
\hline \multirow{6}{*}{ Layers in Snow pack(Spl) } & New Snow & 1 & \multirow{6}{*}{30} & 30 \\
\hline & Fragmented Particles & 1 & & 30 \\
\hline & Rounded grains & 1 & & 30 \\
\hline & Sun Crust & 2 & & 60 \\
\hline & Rounded Grains & 3 & & 90 \\
\hline & Depth Hoar & 4 & & 120 \\
\hline \multicolumn{3}{|c|}{ Snow Pack Stability (SPS) } & 100 & \\
\hline
\end{tabular}

\section{Ranking and Weights}

Avalanche danger assessment is carried out on daily basis during winter months when avalanche susceptible slopes are loaded with snow. The spatial association between a set of evidential themes and known avalanche locations are expressed as the weights of evidence. It involves the analysis of snow, meteorological and terrain parameters. Depending upon the threshold values, different parameters are categorized as critical transitional or non-critical from avalanche data of these parameters. Weights were assigned to the classes of the factors, where higher weight indicates a greater susceptibility to avalanche occurrence. The details of ranks and weights for factors and their classes are presented in Table 3.

The cumulative score equation 1) for a homogeneously represented by physical area; unit estimated and the range is grouped into five classes of favorable avalanche staring zone/snow accumulation Zone(SAZ). This situation is nearly static in nature. From the reported meteorological data the snow pack conditions and fresh snow holding capacity could be established individual zones. The snow related measurements (fewer stations available due to logistic support) are taken continuously during the winter, threshold snowfall and metamorphism that could be deduced in ascertaining its instability as SFA. The observed or reported avalanche activity and stability tests, the modeled snow pack characteristics of individual zones (SPS) can now be used for a detailed stability evaluation. They could be individually or together could be evaluated (ref Table 3 ).

Snow Accumulation Zone $\left.(\mathrm{SAZ})=\sum \mathrm{E}+\mathrm{Sl}+\mathrm{Sd}+\mathrm{Sc}+\mathrm{Sve} 1\right)$ Snow fall Area $\left.(\mathrm{SFA})=\sum \mathrm{Fs}+\mathrm{Ta}+\mathrm{Wd}+\mathrm{Ws} 2\right)$

\section{Snow Pack Stability (SPS) $=\sum$ Ts + Gs + $\mathrm{Gsh}+\mathrm{Sty}+\mathrm{Srs}+\mathrm{Spl3)}$}

Higher cumulative score indicates the highest probability either in terms of snow accumulation or snow fall or snow pack stability. The spatial distribution of SFA a region and continuous monitoring of weather and snow fall conditions would help in the preparedness activities. Figure 4 shows the potential Snow Accumulation Zone regions of the Beas basin.

Rule based avalanche forecasting system using fuzzy logic is widely used Pant and Ganju (2004). In classical logic, true-values of any information are either 0 or 1 which falls under true/falls. In fuzzy logic truth is matter of degree, thus true value ranges between 0 and 1 in continuous manner. Fuzziness occurs when the boundary of piece of information is not clear. Knowledge in the form of IF-THEN rules can be provided by experts or can be extracted from the data. The antecedent part is the collection of conditions connected by AND, OR, NOT logic operators and the consequent part represent part represent its action. IF-THEN rules based classification of potential avalanche potential using terrain parameters (Table 7) and snow accumulation conditions (Table 8) could be derived.

Spatial terrain information, collected were used in the estimating the snow holding capacity (Figure 4). Qualitative and site-wise prediction of avalanches as well as integrated avalanche forecast models require precise weather forecast. Ideally speaking, the numerical forecast of the following weather elements up to $7 \mathrm{~km}$ altitude at least $24 \mathrm{~h}$ in advance, preferably 3 days in advance, is required for the purpose of avalanche forecasting or for the use of avalanche forecast models. 
Table 7. Rule based classification avalanche potential - terrain parameter

\begin{tabular}{|c|c|c|}
\hline \multicolumn{3}{|c|}{$\begin{array}{c}\text { Situation - Altitude of terrain is } 4200 \mathrm{~m} \text { to } 4800 \mathrm{~m} \text {, Terrain is non-forested and full cover with Snow, Terrain's slope is in and around } 29^{\circ} \text { to } 45^{\circ} \text { and } \\
\text { Curvature is Convex and for given meteorological condition }\end{array}$} \\
\hline No & IF Clause & THEN Clause \\
\hline 1 & $\begin{array}{l}\text { If Snow Thickness is more than } 250 \mathrm{~cm} \text { AND Air Temperature is }+4^{\circ} \mathrm{C} \text { to }+18^{\circ} \mathrm{C} \text { AND Snow } \\
\text { Temperature is less than }-10^{\circ} \mathrm{C}\end{array}$ & Avalanche Expected \\
\hline 2 & $\begin{array}{l}\text { If Snow Thickness is } 200 \text { to } 250 \mathrm{~cm} \text { AND Air Temperature is }+4^{0} \mathrm{C} \text { to }+18^{\circ} \mathrm{C} \text { AND Snow Temperature } \\
\text { is less than }-10^{\circ} \mathrm{C}\end{array}$ & Avalanche Expected \\
\hline 3 & $\begin{array}{l}\text { If Snow Thickness is } 150 \text { to } 200 \mathrm{~cm} \text { AND Air Temperature is }+4^{0} \mathrm{C} \text { to }+18^{0} \mathrm{C} \text { AND Snow Temperature } \\
\text { is less than }-10^{\circ} \mathrm{C}\end{array}$ & Avalanche Expected \\
\hline 4 & $\begin{array}{l}\text { If Snow Thickness is } 100 \text { to } 150 \mathrm{~cm} \text { AND Air Temperature is }+4^{0} \mathrm{C} \text { to }+18^{0} \mathrm{C} \text { AND Snow Temperature } \\
\text { is less than }-10^{\circ} \mathrm{C}\end{array}$ & Avalanche not Expected \\
\hline 5 & $\begin{array}{l}\text { If Snow Thickness is } 50 \text { to } 100 \mathrm{~cm} \text { AND Air Temperature is }+4^{\circ} \mathrm{C} \text { to }+18^{\circ} \mathrm{C} \text { AND Snow Temperature is } \\
\text { less than }-10^{\circ} \mathrm{C}\end{array}$ & Avalanche not Expected \\
\hline 6 & $\begin{array}{l}\text { If Snow Thickness is } 0 \text { to } 50 \mathrm{~cm} \text { AND Air Temperature is }+4^{\circ} \mathrm{C} \text { to }+18^{0} \mathrm{C} \text { AND Snow Temperature is } \\
\text { less than }-10^{\circ} \mathrm{C}\end{array}$ & Avalanche not Expected \\
\hline
\end{tabular}

Table 8. Rule based classification- snow accumulation

\begin{tabular}{|c|c|c|}
\hline \multicolumn{3}{|c|}{$\begin{array}{r}\text { Situation - Snow Accumulation is at least more than } 50 \mathrm{~cm} \& \text { there is Snow Grain-Shapes are Depth Hoar, Surface Hoar or/and Faceted and Terrain } \\
\text { conditions like that than }\end{array}$} \\
\hline No & IF Clause & THEN Clause \\
\hline 1 & $\begin{array}{l}\text { IF Slope is } 29^{0} \text { to } 45^{0} \text { AND Altitude is } 4200 \mathrm{~m} \text { to } 4800 \mathrm{~m} \text { AND Curvature is Convex AND ground cover } \\
\text { is full cover with snow }\end{array}$ & Avalanche Expected \\
\hline 2 & $\begin{array}{l}\text { IF Slope is } 29^{0} \text { to } 45^{\circ} \text { AND Altitude is } 3600 \mathrm{~m} \text { to } 4200 \mathrm{~m} \text { AND Curvature is Convex AND ground cover } \\
\text { is full cover with snow }\end{array}$ & Avalanche Expected \\
\hline 3 & $\begin{array}{l}\text { IF Slope is } 29^{0} \text { to } 45^{\circ} \text { AND Altitude is } 3000 \mathrm{~m} \text { to } 3600 \mathrm{~m} \text { AND Curvature is Convex AND ground cover } \\
\text { is full cover with snow }\end{array}$ & Avalanche Expected \\
\hline 4 & $\begin{array}{l}\text { IF Slope is } 29^{\circ} \text { to } 45^{\circ} \text { AND Altitude is } 4800 \mathrm{~m} \text { to } 5400 \mathrm{~m} \text { AND Curvature is Convex AND ground cover } \\
\text { is full cover with snow }\end{array}$ & Avalanche not Expected \\
\hline 5 & $\begin{array}{l}\text { IF Slope is } 29^{0} \text { to } 45^{0} \text { AND Altitude is } 5400 \mathrm{~m} \text { to } 6000 \mathrm{~m} \text { AND Curvature is Convex AND ground cover } \\
\text { is full cover with snow }\end{array}$ & Avalanche not Expected \\
\hline 6 & $\begin{array}{l}\text { IF Slope is } 29^{0} \text { to } 45^{0} \text { AND Altitude is } 4200 \mathrm{~m} \text { to } 4800 \mathrm{~m} \text { AND Curvature is Plane AND ground cover is } \\
\text { full cover with snow }\end{array}$ & Avalanche Expected \\
\hline 7 & $\begin{array}{l}\text { IF Slope is } 29^{0} \text { to } 45^{\circ} \text { AND Altitude is } 3600 \mathrm{~m} \text { to } 4200 \mathrm{~m} \text { AND Curvature is Plane AND ground cover is } \\
\text { full cover with snow }\end{array}$ & Avalanche Expected \\
\hline 8 & $\begin{array}{l}\text { IF Slope is } 29^{\circ} \text { to } 45^{\circ} \text { AND Altitude is } 3000 \mathrm{~m} \text { to } 3600 \mathrm{~m} \text { AND Curvature is Plane AND ground cover is } \\
\text { full cover with snow }\end{array}$ & Avalanche not Expected \\
\hline 9 & $\begin{array}{l}\text { IF Slope is } 29^{\circ} \text { to } 45^{\circ} \text { AND Altitude is } 4800 \mathrm{~m} \text { to } 5400 \mathrm{~m} \text { AND Curvature is Plane AND ground cover is } \\
\text { full cover with snow }\end{array}$ & Avalanche not Expected \\
\hline
\end{tabular}




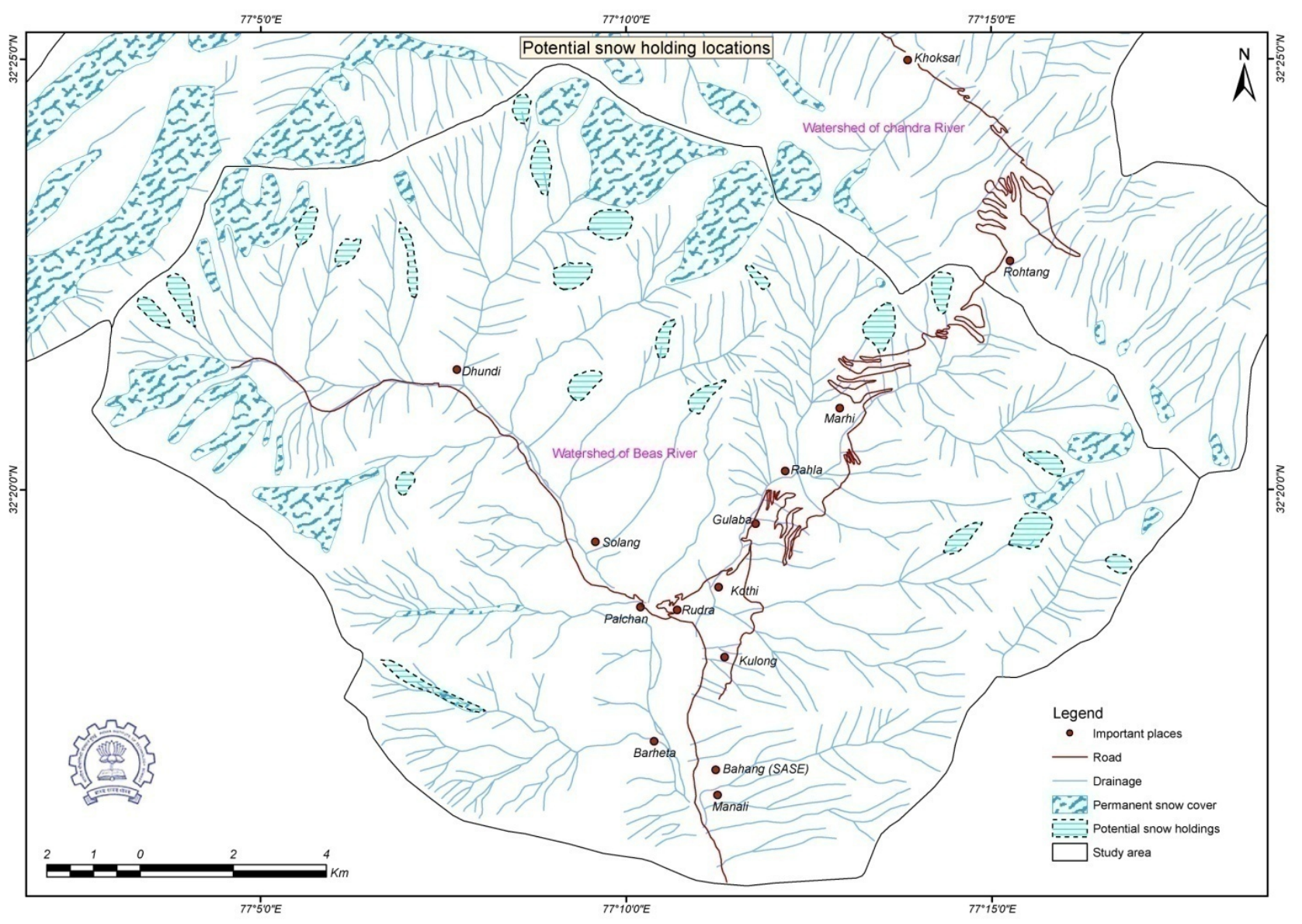

Figure 4. Potential Snow Accumulation Zone (SAZ)

\section{Conclusions}

Snow avalanche vulnerability assessment involves, snow holding capacity of the terrain (static), seasonal snowfall characteristics (vary with prevalent weather / climate dynamic) and snow cover characteristics.

1) Significant parameters related of terrain, meteorology and snow were assigned weightage towards the accumulation and avalanche event based on reported events in Himalayas.

2) Geospatial information was used in identifying potential snow holding areas (avalanche origin). Slope profile generated could be used in estimating the runout distances

\section{Acknowledgements}

This work forms part of the activities carried out as sponsored project supported by Snow and Avalanche Studies Establishment, Chandigarh. Authors would like to acknowledge the support received from RN.Sarwade, Former Director, SASE, Chandigarh and Head, Center of Studies in Resources Engineering, Indian Institute of Technology, Bombay.

\section{REFERENCES}

[1] Ancey C (2009)Snow avalanches,In:Delage P, Schrefler B, (editors), Wiley \& Sons, New York.

[2] Bookhagen, B and Burbank, DW (2010) Toward a complete Himalayan hydrological budget: Spatio-temporal distribution of snowmelt and rainfall and their impact on river discharge, $\mathrm{J}$ Geophysical Research, vol. 115, F03019,doi:10.1029/2009JF001426, 2010

[3] Ciolli M, Tabarelli S andZatelli P (1998) 3D Spatial Data Integration for Avalanche Risk Management, In: Fritsch D, Englich M,ISPRS Commission IV Symposium on GIS Between Visions and Applications, pp 121-127.

[4] Höller P (2007) Avalanche hazards and mitigation in Austria: A review, Natural Hazards, vol43,pp 81-110.

[5] IanMcCammonand Pascal Hageli (2007) An evaluation of rule based decision tools for travel in avalanche terrain, Cold Regions Science and Technology,vol 47, pp193-206.

[6] ICSI (1990) The International classification of seasonal snow on the ground, International Commission on Snow and Ice of the International Association of Scientific Hydrology, pp.23.

[7] Kaur R, Saikumar D, Kulkarni, AV and Chaudhary BS (2009) 
Variations in snow cover and snowline altitude in Baspa Basin, Current Science,vol96, pp1255-1258.

[8] Laternser, M and Schneebeli, M (2002) Temporal trend and spatial distribution of avalanche activity during the last 50 years in Switzerland, Natural Hazards vol27 (3), pp 201-230.

[9] McClung DM (2000) Predictions in avalanche forecasting, Annals in Glaciology, pp.31.

[10] McClung DM and Schaerer (1993) The avalanche Handbook, The Mountaineers, Seattle, USA.

[11] Mock CJ and Birkeland KW (2000) Snow avalanche climatology of the Western United States Mountain ranges, Bulletin of the American Meteorological Society, Vol 81, pp2367-2392.

[12] Pant LK andGanju A (2004) Fuzzy rule based system for prediction of direct action avalanche, Current Science, Vol 87 (1),pp. $99-104$.

[13] $\mathrm{Pu}, \mathrm{Z} ., \mathrm{Xu}, \mathrm{L}$ and Salomonson, V (2007) MODIS/Terra observed seasonal variations of snow cover over the Tibetan Plateau, Geophysical Research Letters, Vol.34, L06706, doi:10.1029/2007GL029262.
[14] Ramussen J (1982) A taxonomy for describing human malfunction in industrial installations, Journal Occupational Accidents, Vol 4, pp.314-5.

[15] Saaty TL (1980)The Analytical Hierarchy Process. McGraw-Hill, New York

[16] Sharma SS andGanju A (2000) complexities of avalanche forecasting in Western Himalaya - an overview, Cold Regions Science and Technology, Vol 31, pp 95 - 102.

[17] Singh D and Ganju A (2006) Improvement in nearest neighbour weather forecast model performance while considering the previous days forecast for drawing forecast for the following day; Current Science, vol91(12),pp1686-1691.

[18] Scheweizer J, Kronholm K, Jamieson JB and Birkeland KW (2008) Review of spatial variability of snowpack properties and its importance for avalanche formation, Cold Region Science and Technology, vol51 (2-3) 253-272.

[19] SeluckLevent (2013) An avalanche hazard model for Bitlis Province, Turkey, using GIS based multi-criteria decision analysis, Turkish J Earth Science, vol22, pp.523-535. 